\title{
THE AUSTRALIAN ROYAL COMMISSION INTO INSTITUTIONAL RESPONSES TO CHILD SEXUAL ABUSE
}

Warwick Middleton, Pam Stavropoulos, Martin J. Dorahy, Christa Krüger, Roberto Lewis-Fernández, Alfonso Martínez-Taboas, Vedat Sar, Bethany Brand

Pam Stavropoulos, Ph.D.

Head of Research and Clinical Practice,

Adults Surviving Child Abuse,

Sydney, Australia,

pstavropoulos@iprimus.com.au.

Martin Dorahy, Ph.D.

Associate Professor,

Department of Psychology,

University of Canterbury,

New Zealand.

martin.dorahy@canterbury.ac.nz

Christa Krüger, M.D.

Professor,

Department of Psychiatry,

University of Pretoria,

South Africa.

christa.kruger@up.ac.za

Roberto Lewis-Fernández, M.D.

Professor,

Department of Psychiatry

Columbia University

New York State, USA

rlewis@nyspi.columbia.edu

Alfonso Martínez-Taboas, Ph.D.

Associate Professor,

Carlos Albizu University,

San Juan, Puerto Rico.

AMartínez@albizu.edu

Vedat Sar, M.D.

Professor,

Department of Psychiatry

Istanbul Faculty of Medicine

Istanbul University, Turkey.

President, European Society for Traumatic Stress Studies (ESTSS)

vsar@istanbul.edu.tr

Bethany Brand, Ph.D.

Professor of Psychology,

Towson University,

Maryland, USA,

BBrand@,towson.edu 


\section{Corresponding Author:}

Adjunct Professor Warwick Middleton

MB BS, FRANZCP, MD.

Chair, The Cannan Institute,

Director, Trauma \& Dissociation Unit,

Belmont Hospital, Carina 4152

Direct correspondence to:-

Suite 4D, 87 Wickham Tce

Brisbane 4000

Ph: (07) 38314466

Fax: (07) 38314477

Mobile: 0417629813

Email: warmid@tpg.com.au

An old adage regarding social gatherings advises against discussing sex, politics, or religion. The Australian Royal Commission into institutional aspects of child sexual abuse grapples with all three. For a government to choose to focus national priority on an issue that so fundamentally entwines these contentious issues speaks of a rising awareness about the profoundly destructive psychological effects of child sexual abuse (and related abuses). It also attests to the political force represented by a growing number of vocal citizens and consumer organizations who will no longer accept institutional silence and inaction.

In 1992, Judith Herman highlighted that in the absence of a political movement, "it has never been possible to advance the study of psychological trauma" (pg 32). This is because concerted alliances must be sufficiently strong to transcend the powerful societal mechanisms which inhibit expression of disquieting and incriminating truths. Three times over the past century, she suggested, "a particular form of psychological trauma has surfaced into public consciousness" (Herman, 1992, pg. 9) in conjunction with a political movement - hysteria arising in sexually abused girls (in the context of the republican movement of late nineteenth century France), shell shock or combat neurosis (in relation to the anti-war protests which culminated around the Vietnam War), and opposition to sexual and domestic violence (in the context of second-wave feminism).

In April 2012 it was revealed that confidential police reports had documented the suicides of at least 40 individuals sexually abused by Catholic clergy in Victoria (McKenzie, Baker \& Lee, 2012). The announcement on November 12, 2012 of the creation of the Australian Royal Commission into Institutional Aspects of Child Sexual Abuse followed in the wake of the Victorian Parliamentary Committee Inquiry into Child Sexual Abuse Within Religious Organizations that began its public hearings on October 19, 2012. It also followed the subsequent announcement by the NSW Government on November 9, 2012 of the establishment of a Special 
Commission of Inquiry headed by NSW Deputy Crown Prosecutor, Margaret Cunneen SC, into police investigations of alleged paedophile priests located in the Hunter Region of NSW. Thus the Royal Commission has been largely catalysed by child abuse allegations and activities within religious settings, particularly involving the Catholic Church, though its reach includes the activities of all institutions.

Preliminary evidence provided to the Victorian Parliamentary Inquiry by the Victoria Police showed that between January 1956 and June 2012 there were 519 "distinct victims" in Victoria, with $71.3 \%$ abused within the Catholic Church system, $7.1 \%$ within the Anglican Church, 6.9\% within the Salvation Army, and 3.5\%, within the Jewish religious system (Cahill, 2012). In the United States, the Catholic Church accepts that plausible allegations of child sexual abuse have been made against $5.3 \%$ of Catholic priests, although others claim the true figure could be 6-9\% (Robertson, 2010).

The immediate precipitant to the establishment of the NSW Special Commission was an open letter to the Premier by Detective Chief Inspector Peter Fox. In this letter, Fox stated, "I can testify from my own experience the [Catholic] Church covers up, silences victims, hinders police investigations, alerts offenders, destroys evidence and moves priests to protect the good name of the Church." Fox claimed he had "irrefutable" evidence of a cover-up that involved a number of diocesan bishops (Sydney Morning Herald, 2012). He aired his concerns nationally when he was interviewed on ABC Television's Lateline on November 8, 2012. Removed in 2010 from his investigation of child sex abuse by priests, Fox reported a Police smear campaign against him which included threatening anonymous letters on Police letterhead and the spreading of rumors that he was mentally unstable (Levy, 2012).

A palpable sense of shock is evident in contemporary news coverage, as the tipping point for the Catholic Church child sex abuse scandal in the US was reached in early 2002. Writing in Time magazine, Sullivan, a journalist commentator, stated in March 2002, "In the past month, it has been revealed that more than 70 priests in the archdiocese of Boston - out of a total of less than 700 - have been accused of the sexual abuse of children. That's 1 in 10 . Worse, when evidence of these crimes has come to light, the church hierarchy has done everything in its power to hush it up, pay secret damages to the victims and, in many cases, do nothing but reassign pedophile priests to other parishes, where they can commit abuse again" (pg 39).

By 2012 the worldwide Catholic Church had paid out around $\$ 3$ billion to settle civil suits arising out of the sexual abuse of children by members of its clergy. Over 6,100 priests in the United States alone were deemed by their Church to be "credibly" or "not implausibly" accused of sexual crimes committed against in excess of 16,000 underage victims (D’Antonio, 2013).

The crisis for the US Catholic Church continues to unfold. In February 2013 Archbishop José H. Gomez announced that Cardinal Mahoney (archbishop for a quarter of a century of America's largest diocese, Los Angeles, which in 2007 reached a $\$ 660$ million settlement with more than 500 victims) would be stripped of his public duties for not doing more to protect children who were sexually abused by priests and whose ongoing abuses he was heavily involved in covering up. In the same month that Benedict XVI announced his retirement, the disgraced Mahoney was 
then readying himself to be a part of the conclave that would elect the new pope (Washington Post 2013).

In his prepared statement given to the Victorian Parliamentary Inquiry on May 28, 2013, Cardinal Pell, Australia's most senior Catholic clergyman, stated,

"I acknowledge again with shame and great sadness the pain caused by the sexual abuse of children and apologise again to all those who suffered abuse from Catholic priests, religious and lay church workers... In many cases the harm that has been done by sexual abuse causes lifelong suffering. In some cases it has even led to suicides, a tragedy which fills me with horror and sadness both for those who have died in this way and for those who love them... Like Archbishop Hart and the other Australian bishops, I have apologised on a number of occasions for these terrible crimes."

Whilst an issue for all churches, the Catholic Church has eclipsed other religious institutions in the extent of child sexual abuse allegations made against it. Unlike other churches it is headquartered in its own city-state, the Vatican, a state administered by "God's vicar on Earth" (the current incumbent in a lineage that stretches back to St Peter). Bishop Robinson (2010), himself a survivor of childhood sexual abuse, reflects on the culture of his church and writes about the "notable and extraordinary absence of guidance or direction from the Pope" in relation to the sexual abuse of minors. "Older values have for a thousand years included secrecy, the covering over of problems and the protection of the good name of the Church" (pg. 8). Robinson goes on to observe; "[u]ntil the Church puts celibacy on the table for serious discussion, people will simply not believe it is serious about abuse" (pg. 19).

The last time an Australian Royal Commission examined institutional aspects of child sexual abuse was via the Wood Royal Commission in NSW, where the focus was largely limited to a circumscribed group of Wollongong-based politicians and clergymen. Frank Arkell (Lord Mayor of Wollongong for 17 years and NSW state parliamentarian) was personable, and at times popular. He was, however, accused of being part of a paedophile grouping centered on Tony Bevan, the former Lord Mayor of Wollongong. This group also included Brother Michael Evans, Principal of Edmund Rice College (who suicided as the NSW Commission on Paedophilia was looking to question him about child-sexual abuse allegations) and former Wollongong councillor Brian William Tobin (who in April 1996 also committed suicide). Fr. Peter Cominsoli (sentenced to 24 months of jail in October 1994 after pleading guilty to the indecent abuse of altar boys) was publicly exposed at the same time as his friend Brother Evans (Brown, 1996). Evans' victims included pupils at Edmund Rice College in Wollongong and St Patrick's College in Strathfield, Sydney.

Arkell was a particular catalyst for the Wood Commission's additional focus on paedophilia (that was sought at great personal cost by the NSW MP, Deirdre Grisovin, who had named him as a paedophile in a speech in state parliament in 1994). Arkell was murdered on $27^{\text {th }}$ June 1998 by a man who later described Arkell to police as a paedophile and a "bad man." At the time, Arkell was awaiting trial on four charges of drugging and raping two teenage boys (Kidd, 2013). 
While only one of this widely-reported alleged Wollongong paedophile grouping made up of politicians and churchmen lived to stand trial, other Australian politicians have been convicted of sexual offences against children. These include Keith Wright, Bill D'Arcy, Milton Orkopoulos, and Terry Martin (Wikipedia, 2013), while Bob Collins died/suicided after being charged with multiple child sex abuse offences (Murphy, 2007).

Abusers are found in all professions, including those who make our laws. But the power and protection afforded our lawmakers makes their involvement particularly difficult to document and prosecute. The unfinished business of attempting to document the full extent of abuses associated with the Wollongong and other groupings is inevitably going to occupy some substantial part of the Commission's time.

The Australian Royal Commission represents an important opportunity. There has been one prior dedicated Royal Commission into aspects of sexual abuse in institutions - the Ryan Royal Commission in Ireland which investigated abuse by the Catholic clergy. This was, however a somewhat limited investigation that extended over nine years, finally concluding in 2009. It also had to contend with the departure of the original commissioner after three years. In the end it had to be buttressed by some 13 different parallel local enquiries (The Conversation, 2012).

Thus there has never before been a comparable far-reaching enquiry along generally similar lines to those of the Australian Commission, which can look at any private, public or non-government organization that is, or was in the past, involved with children, and which includes government agencies, schools, sporting clubs, orphanages, foster care, and religious organizations. We would be wise to be informed by lessons learned from South Africa's Truth and Reconciliation Commission (SA TRC), which was established by Nelson Mandela in 1995. Intended to build a new society without retribution, it functioned on the premise that any individual could be granted amnesty if he or she was prepared to fully disclose and confess his/her role in crimes undertaken during the apartheid era. In this way, many family members discovered for the first time how loved ones died.

The work of the SA TRC hinged, and its success depended, upon cooperation of willing parties on both sides who were committed to preserve some form of relationship (Krüger, 2006). As with the TRC, some innovative thinking may be necessary for the Australian Commission, and the latter's ultimate result may need to be weighted more towards the validation of victims than the prosecution of all perpetrators. Yet while some pragmatic decisions will need to be made, given the seriousness of many relevant crimes, it would be very unsatisfactory if three years after the Commission finishes its report no individual has been prosecuted (as has been the case with Ireland's Ryan Commission; The Conversation, 2012).

Even before the Australian Commission heard its first testimony, there was criticism from some quarters, claiming that it was a political distraction, or that it would find nothing that was not already known. An example of such commentary is that of Walters and Unwin (2013):

"As a distraction, the Commission of Inquiry into Sexual Abuse in Institutions has already bestowed its maximum benefit on our Prime Minister, briefly 
deflecting attention from questions of fiscal abuse in Canberra and allegations of criminal activity concerning her connection with a lover and trade union figure while still a Melbourne labour lawyer. The Romans gave the people circuses when times were bad and, like the Royal Commission, circuses can be entertaining in a barbaric kind of way, though they don't really help anything very much."

It is rare for a government of a country such as Australia to commit itself to the close examination of the world in which abuse and exploitation are commonplace, and in which societal structures have exerted power and control to the extent that the magnitude of such practices has until recent times remained largely screened from public consciousness. The most effective way for abuse and exploitation to flourish is for there to be silence, and silence is the foundation of the illusion that there is little about which to be concerned. When society chooses silence, the victims of child abuse remain both at the whim of perpetrators and overlooked by institutions which are supposed to protect them. They are left to carry the burden of shame, fear, conditioning, and distorted attachments that characterize their childhoods. Indeed, after reviewing many prevalence and incidence studies of child sexual abuse, Bolen (2001) concluded that only $20 \%$ of childhood sexual abuse cases come to the attention of authorities.

For those abused by members of institutions who almost invariably exploit the sense of shame of their victims, and who often issue threats, including that of death, it is necessary and validating that such victims, have their testimony heard by appointed well-credentialed individuals whose task is to thoroughly investigate such abuses and report their findings and recommendations to the Federal Government. Having accompanied such an individual as he gave evidence to Commissioners in a closed session, one of the authors (WM), can attest from first-hand observation to the substantial personal fortitude that is required to articulate details of something highly traumatizing and laced with shameful feelings, and how such courage is reciprocated by a deeply respectful and inquiring stance on the part of the Commissioners. For many victims, it will be the first time that their experience of institutionally-based childhood sexual abuse has been articulated in the presence of senior and credible representatives of their society.

When we penetrate the smokescreen of controversies regarding false accusations, "recovered memories," "recanters," references to "Satanic Ritual Abuse," and the incorporation of elements of cultural myths into some accounts, we are left with the reality that in the vast majority of cases it is not the over-reporting or exaggeration of trauma that is the principal problem. Rather it is society's unwillingness to know, the perpetrators' strongly motivated efforts to hide their criminal acts, and the relative ease they are often afforded by societal institutions and practices in doing so.

Society is replete with structures and organizations that have "in-house" arrangements for how matters pertaining to abuse and exploitation are "managed" and covered up. These become channels for perpetrators seeking to avoid accountability. It has generally been the case that women and children have had the least real protection, in that they are particularly vulnerable to sexual abuse, whilst at the same time they are frequently characterized as unreliable or untruthful witnesses as part of the attempt to disguise abuse. Many have commented on the ways in which the sexual exploitation 
of a child or an adult by an individual in a situation where there is a major power differential, brings with it the secrecy, the threats, the manipulation of shame, and the need to discredit the victim, that so characterize the incest dynamic. Dealing effectively with the major problem of incestuous families, including the substantial number in which incest is ongoing into adulthood, is a major and defining challenge for Australia and for our global community.

The Australian Royal Commission into Institutional Aspects of Child Sexual Abuse can also be conceptualized as representing a sort of "proxy" investigation at two other levels. In the first instance, it is an investigation of child sexual abuse associated with institutions. While the majority of child sexual abuse occurs in families rather than in large collective institutions, the dynamics are frequently so similar that what is found with respect to 'macro' institutions parallels the sorts of incest dynamics endlessly seen in families. While an investigation into institutional abuses and the mechanisms that operate to protect abusers will not identify those who abuse children in family contexts, it will, if conducted properly, bring to light some intra-familial abuse. This is because there are many examples of incestuous abuse which merge with elements of organized abuse. A national enquiry into institutional abuse and its cover-up is a necessary major first step for a society which is finally grappling with the true extent of intra-familial abuse.

The second "proxy" element to the Australian Royal Commission is that the sorts of institutional child sexual abuse in Australia are, we suspect, generally similar to those in many other countries. If done well, the Royal Commission's findings in Australia may be more broadly applicable to many societies that, for a variety of reasons, have thus far baulked at establishing similar investigations in their own countries. A wellconducted and internationally supported Australian Royal Commission will provide politicians, mental health professionals, international trauma societies, and national consumer organizations with compelling leverage to assist in addressing both local and international abuse.

All contemporary societies face broadly similar challenges as we awaken to the reality that widespread sexual abuse of children is an issue that has enormous societal, no less than individual, costs. While confronting to contemplate, serial paedophile abusers responsible for the abuse of many hundreds of children arguably cause more deaths and more pain than do some serial killers. Yet many child sexual abusers have managed to repeatedly offend for decades under the protective embrace of organizations that effectively sponsor their opportunities for such activities.

With the advent of the Royal Commission, Australia has a once-in-a-generation opportunity to do something of importance that stretches beyond the needs of Australians. It could come to represent an enduring global benchmark for addressing a deeply troubling aspect of humanity that is as old as civilization. In so doing, it would add a further dimension to the spectrum of basic human rights considerations. It would help spread the reach of true democracy to many who have experienced little protection from existing societal structures in respect to the hierarchical oppressors who have ruled and/or badly damaged their lives.

Propelled by accumulating evidence of sexual abuse of children by mainstream social institutions, and to extend Herman's (1992) stages of focused public awareness, 
perhaps the Australian Royal Commission represents a fourth historical moment. This is one in which the populace, now digitally connected in a manner hitherto impossible, is informed by decades of trauma research that will allow comprehensive and systematic examination of the sexual abuse perpetrated on children by the very institutions which are charged with their protection.

References:

Bolen RM (2001) Child Sexual Abuse: Its Scope and Our Failure. New York: Kluwer.

Brown M (1996) Police were slow to act on clergy sex assault claim. Sydney Morning Herald, 16 April. Retrieved from http://tiny.cc/qqrosw on 03-02-13.

Cahill D (2012) An unholy mess: addressing sexual abuse in the Catholic Church. ABC Religion and Ethics, 21 November. Retrieved from http://tiny.cc/vsrosw on 26$01-13$.

D'Antonio, M. (2013). Mortal sins: sex, crime, and the era of Catholic scandal. New York: Thomas Dunne.

Herman, J (1992) Trauma and Recovery: the aftermath of violence - from domestic abuse to political terror. New York: Basic Books.

Kidd PB (2013) Mark Mala Valera: the Butcher of Wollongong. Retrieved from http://tiny.cc/92rosw on 03-02-13.

Krüger C (2006) Spiral of growth: A social psychiatric perspective on conflict resolution, reconciliation, and relationship development. In Trauma, Truth and Reconciliation: Healing Damaged Relationships, chapter 2, pp. 29-65. NN Potter (ed.), Oxford: Oxford University Press.

Levy M (2012) 'Satisfied' whistleblower weighs future in the force. Smh.com.au 13 November. Retrieved from http://tiny.cc/25rosw on 26-01-13.

McKenzie N. Baker R and Lee J (2012) Church's suicide victims. The Age, 13 April. Retrieved from http://tiny.cc/cgsosw on 26-01-13.

Murphy D (2007) Minister raped me in his Parliament office. Sydney Morning Herald, 26 September. Retrieved from http://tiny.cc/pisosw on 03-12-13. Olafson E (2011) Child sexual abuse: demography, impact, and interventions. Journal of Child and Adolescent Trauma, 4: 8-21.

Pell G (2013) Statement from his eminence Cardinal George Pell on the Victorian Parliamentary Inquiry, 28-05-13. Retrieved from http://www.sydneycatholic.org on 02-06-13. 
Robertson G (2010) The Case of the Pope. London; Penguin.

Robinson G (2010) Confronting Power and Sex in the Catholic Church. Mulgrave, Victoria: John Garratt.

Sullivan A (2002) They still don't get it. Time, $4^{\text {th }}$ March, 39.

Sydney Morning Herald (2012) Premier challenged to launch sex abuse investigation. Smh.com.au, 9th November. Retrieved from http://tiny.cc/sksosw on 26-01-13.

The Conversation (2012) Cross to bear: Ireland's Ryan Commission into child abuse in the Catholic Church. The Conversation, $19^{\text {th }}$ November. Retrieved from http://tinyurl.com/mokf3ws on 21-07-13.

Walters, M. \& Unwin, A. (2013) A sorry excuse for a Royal Commission. Quadrant Online 17 April. Retrieved from http://tinyurl.com/nyzpmz5 on 21-07-13.

Washington Post Editorial Board (2013) The sins of Cardinal Mahony. Washington Post 14 February. Retrieved from http://tiny.cc/gnsosw on 18-02-13.

Wikipedia (2013) List of Australian politicians convicted of crimes. Retrieved from http://tiny.cc/d6sosw on 03-02-13. 